\title{
Temporal variations of plume activities before the 8 October 2016 eruption of Aso volcano, Japan, detected by ground-based and satellite measurements
}

\author{
Masaaki Morita* ${ }^{*}$
}

\begin{abstract}
At many volcano observatories, measurements of the plume height are frequently applied. On the other hand, the recent development of the satellite measurements enables the monitoring of the $\mathrm{SO}_{2}$ mass emitted by the passive degassing at sufficient temporal resolution. Using these two techniques, this study focuses on the degassing activity before the 8 October 2016 phreatomagmatic eruption of Aso volcano, Japan. Here we show the temporal variations of the plume height, the $\mathrm{SO}_{2}$ mass, and ground-based $\mathrm{SO}_{2}$ flux during 6 months before the eruption. Our result shows similar temporal changes of them, especially for the maxima and the increase, respectively, in about 2 months and 6 days before the eruption. This result indicates that the degassing system had been stable during the whole study period, but the accumulation of volcanic gas in the conduit since August might trigger the phreatomagmatic eruption. These techniques can be sufficient to monitor the degassing activity and to detect its precursory change.
\end{abstract}

Keywords: Aso volcano, Volcanic eruption, Monitoring camera, Volcanic plume, Plume height, $\mathrm{SO}_{2}$, OMPS

\section{Introduction}

Phreatomagmatic eruptions are triggered by an interaction of magma with shallow hydrothermal systems (Rouwet et al. 2014). Related to the interaction of ascending magma with the hydrothermal systems, precursory changes of gas geochemistry and fumarolic activity have been documented at some volcanoes (Barberi et al. 1992; de Moor et al. 2015; Sano et al. 2015). Along with the observations of gas geochemistry, visual monitoring of volcanic plumes using cameras is also conducted at many volcanoes (Fukui 1995; Terada et al. 2003, 2005; Behncke et al. 2009; Arason et al. 2011; Fukui and Terada 2013; Shimbori and Fukui 2013). At many Japanese volcanoes, plume height is monitored as an indicator of the apparent intensity of the volcanic plume (Volcanological Division, Seismological and Volcanological Department,

\footnotetext{
*Correspondence: aki.morita@aist.go.jp Geological Survey of Japan, National Institute of Advanced Industrial Science and Technology, Central 7, Higashi 1-1-1, Tsukuba 305-8567, Japan
}

JMA 2014). However, the visibility of the plume is highly affected by atmospheric conditions (Matsushima and Shinohara 2006), and the plume height is also influenced by wind conditions (Bursik 2001). Therefore, to monitor the plume activity, the apparent intensity of the plume has rarely been treated quantitatively.

The supply of magma and volcanic gas is frequently monitored as the emission rate of sulfur dioxide $\left(\mathrm{SO}_{2}\right)$ using ground-based (Stoiber et al. 1983; Galle et al. 2002) and satellite remote sensing techniques (Krueger 1983). Concerning the satellite remote sensing, satellite measurements of $\mathrm{SO}_{2}$ emissions to date are not limited in volcanic plumes of large explosions but also applied to those of passive degassing (Carn et al. 2008; Campion 2014). These previous studies have revealed that the satellite measurements of $\mathrm{SO}_{2}$ emissions have sufficient precision and temporal resolution to be used for the monitoring. Although the satellite measurements have a potential to monitor the passive degassing activity, the application of them is still rare at many volcano observatories. 
This study focuses on the precursory changes of the plume activity before the phreatomagmatic eruptions using the ground-based monitoring of the plume intensity and the satellite measurements of $\mathrm{SO}_{2}$ emissions. We evaluate the plume intensity as the plume height and compare it with the $\mathrm{SO}_{2}$ mass estimated by the satellite measurements. Comparing a semiquantitative value (plume height) with a quantitative value $\left(\mathrm{SO}_{2}\right.$ mass), we appraise an efficiency of the plume monitoring. As a case study, we choose the phreatomagmatic explosion of Aso volcano, Japan, on 8 October 2016. We show the temporal variations of the plume height and $\mathrm{SO}_{2}$ mass during 7 months before and after the explosion.

\section{Aso volcano}

Aso volcano is one of the most active volcanoes in Japan and consists of a caldera with diameters of $25 \mathrm{~km}$ in north-south and $18 \mathrm{~km}$ in east-west and post-caldera central cones. The only active cone is the Nakadake Volcano with compositions ranging from basalt to basaltic andesite (Ono and Watanabe 1985). Among seven craters of the volcano, only the northernmost crater (the Nakadake first crater, Fig. 1) has been active in the past 80 years (Ono and Watanabe 1985). The crater is filled with hot $\left(40-80^{\circ} \mathrm{C}\right)$ and hyper-acidic $(\mathrm{pH}<1)$ lake water during calm periods (Miyabuchi and Terada 2009; Ohsawa et al. 2010; Terada et al. 2012; Shinohara et al. 2015), and the crater lake is maintained by a continuous supply of volcanic fluids from depth (Terada et al. 2012; Terada and Hashimoto 2017). Volcanic gas is persistently emitted from the lake surface and a fumarolic area on the southern wall of the crater. The $\mathrm{SO}_{2}$ flux in calm periods ranges in approximately 200-400 tons day ${ }^{-1}$ (JMA 2017).

After a series of intermittent ash emissions and Strombolian explosions from November 2014 to May 2015, a phreatomagmatic explosion occurred on 14 September 2015 (Miyabuchi et al. 2018). It was followed by a small phreatomagmatic explosion on 23 October 2015 and some minor phreatic explosions from December 2015 to March 2016 (JMA 2017). In March 2016, the lake water started to refill the crater bottom, and the surface area of the lake increased to $70 \%$ of the crater bottom in July 2016. During March and September 2016, quite minor wet ash emissions from the crater bottom were frequently observed (JMA 2017). A minor explosion occurred at 21:52 JST (UTC + 09:00) on 7 October 2016 followed

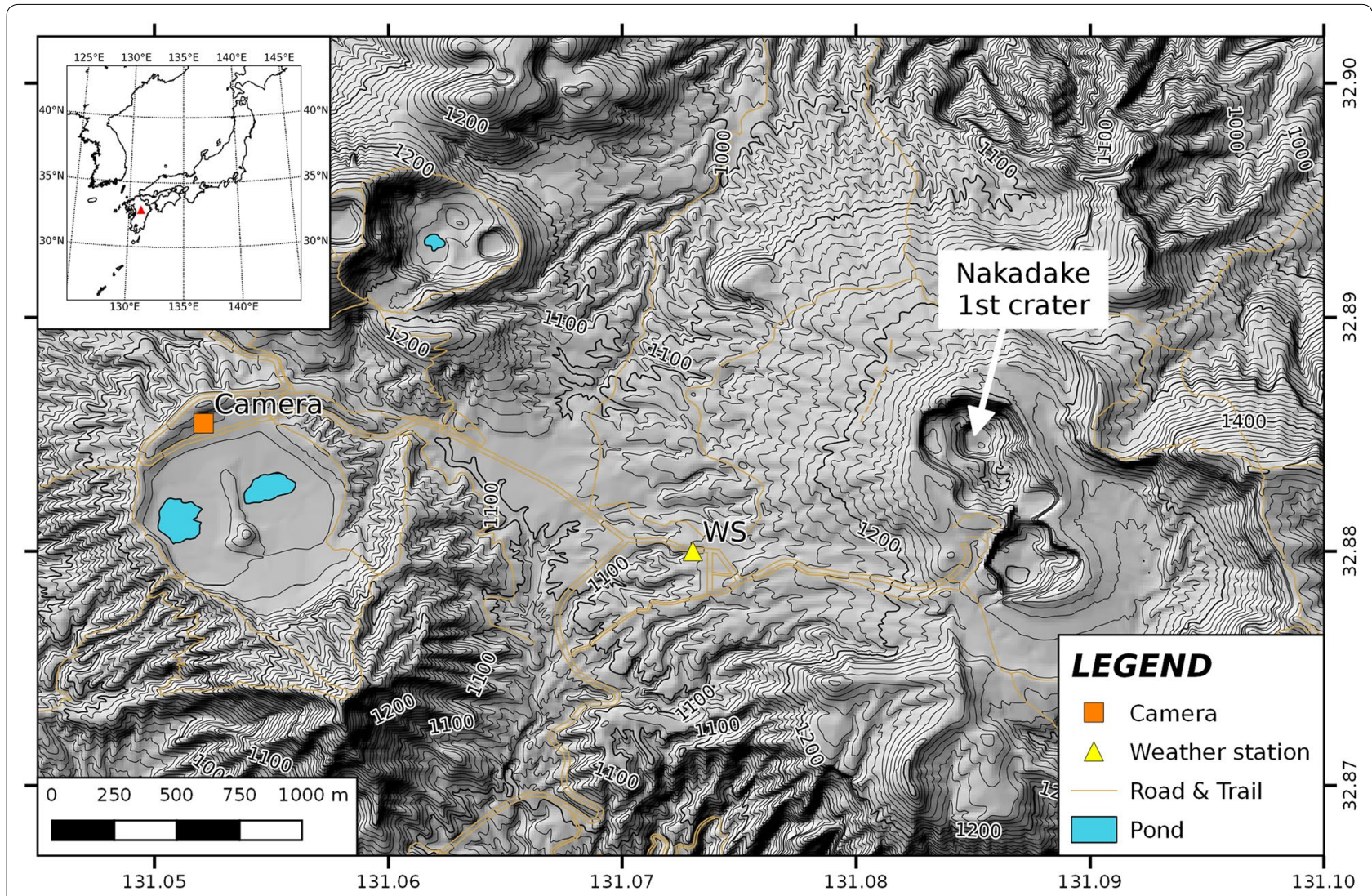

Fig. 1 Location of monitoring camera and the crater of Aso volcano. Location of Aso volcano is depicted with the red triangle in the inset. Data of the base map are from Geospatial Information Authority of Japan 
by a large phreatomagmatic explosion at 01:46 JST on 8 October 2016 (JMA 2017). For the latter explosion, the top of the plume height observed by a geostationary meteorological satellite Himawari- 8 was estimated to be $13-14 \mathrm{~km}$ asl (Ishii et al. 2018). The total eruptive mass of the 7-8 October explosions was estimated to be 6.0$6.5 \times 10^{6}$ tons, and the juvenile magma erupted by the explosions accounted for $20 \%$ of the deposits (Miyabuchi et al. 2017).

\section{Analysis method}

To estimate the plume height between April and October 2016, we used the monitoring video camera that was maintained by JMA (WV-E850, Panasonic Corp.) and located at $3.1 \mathrm{~km}$ west of the crater (Fig. 1). The $30-\mathrm{Hz}$ video was captured every $2 \mathrm{~s}$, and the captured image was compressed and saved into a jpeg file with a size of $640 \times 480$ pixels. To dismiss short-term (from seconds to minutes) disturbances by wind and other meteorological conditions, the images of an hour (1800 images at maximum) were first composited into one image. Then, based on the composite image, the plume height was estimated manually. In this study, the plume height is presented in meters above the crater rim $(1270 \mathrm{~m}$ asl at the western side of the crater where the crater rim is visible in the image). From April to October 2016, the crater had always been filled with the lake water, and the volcanic plume had persistently risen from the lake surface and the fumarolic area on the southern wall of the crater (JMA 2017). This approximately constant geometry of the source of the volcanic plume hardly affects the estimation of the plume height.

The analysis of $\mathrm{SO}_{2}$ mass between April and October 2016 was performed using the Ozone Mapping and Profiler Suite (OMPS) nadir mapper instrument (Flynn et al. 2014; Seftor et al. 2014) onboard the NASA/NOAA Suomi National Polar-orbiting Partnership (Suomi-NPP) satellite. Suomi-NPP is in a polar orbit with a local equator crossing time of 13:30. The instrument measures UV (300-380 nm) backscatter radiances and provides daily global mapping data of ozone, $\mathrm{SO}_{2}$, and other trace gases. The spatial resolution of the instrument is $50 \times 50 \mathrm{~km}$ at nadir. The $\mathrm{SO}_{2}$ vertical column densities (VCDs) retrieved by the algorithm of $\mathrm{Li}$ et al. $(2013,2017)$ are provided by NASA Goddard Space Flight Center (https ://avdc.gsfc.nasa.gov/pub/data/satellite/Suomi_NPP/ L2/NMSO2-PCA-L2/). In this study, to analyze the $\mathrm{SO}_{2}$ mass of the passive degassing, the $\mathrm{SO}_{2} \mathrm{VCDs}$ assuming an $\mathrm{SO}_{2}$ profile centered in the planetary boundary layer (PBL, a center of mass altitude of $0.9 \mathrm{~km}$ asl) and the lower troposphere (TRL, a center of mass altitude of $3 \mathrm{~km}$ asl) were normally used, whereas those in the upper troposphere (TRU, a center of mass altitude of $13 \mathrm{~km}$ asl) were used only in the analysis of the $\mathrm{SO}_{2}$ mass emitted by the 8 October 2016 eruption. Although $\mathrm{SO}_{2} \mathrm{PBL}$ might overestimate the $\mathrm{SO}_{2}$ mass considering of an altitude of the crater rim (1270 m asl), the main topic in this study is passive degassing and thus we will mainly focus on $\mathrm{SO}_{2} \mathrm{PBL}$ in the following sections. The $\mathrm{SO}_{2} \mathrm{VCDs}$ are presented in DU (Dobson units, $1 \mathrm{DU}=2.69 \times 10^{16} \mathrm{~mol}-$ ecules $\mathrm{cm}^{-2}$ ).

In each daily map of the $\mathrm{SO}_{2} \mathrm{VCDs}$, the volcanic $\mathrm{SO}_{2}$ signal was basically weak, and the volcano was sometimes covered with cloud. Therefore, the daily $\mathrm{SO}_{2}$ mass was not basically estimated in this study. Instead, the averaged $\mathrm{SO}_{2}$ mass for PBL and TRL in certain periods (10 days and 1 month) was calculated following the method presented by Carn et al. (2008) and Campion (2014). The daily $\mathrm{SO}_{2}$ VCDs in each period were first gridded in a step of $0.1^{\circ}$, and then, they were stacked and averaged by the number of days. The time-averaged volcanic $\mathrm{SO}_{2}$ mass was calculated by summing the $\mathrm{SO}_{2}$ VCDs in a volcanic region ( $4^{\circ}$ in longitude $\times 2^{\circ}$ in latitude, red rectangle in Figs. 3 and 4) that were higher than a threshold value (mean + standard deviation of the $\mathrm{SO}_{2} \mathrm{VCDs}$ in an $\mathrm{SO}_{2}$-free region for each period, blue rectangle in Figs. 3 and 4). Further details on the analysis method of $\mathrm{SO}_{2}$ mass and the influence of cloud cover are provided in the supporting information of this article (Additional file 1: Sections 1 and 2).

\section{Results}

Time series of the estimated plume height and representative examples of the composite image are shown in Fig. 2. We were not able to estimate the plume height for dilute plumes or plumes surrounded by clouds, especially when the plume flew near the ground. This difficulty is the reason that the plume height values shown in Fig. 2 are almost more than $100 \mathrm{~m}$. However, in some cases, the plume height was successfully estimated for dilute plumes (examples shown in Fig. 2; 13:00 JST, 12 May, and 00:00 JST, 12 August). The influence of wind and atmospheric conditions on the plume height is discussed in detail in the supporting information (Additional file 1: Section 3 and Figures S1 and S2). As a brief conclusion of the supporting information, variations of the plume height in a week-month scale are represented by an envelope of the maximum plume height in that scale in Fig. 2.

In Fig. 2, some maxima of the plume height in a weekmonth scale were found at 10 April, 12 May, 3 June, 10 August, 6 September, and 7 October. Especially at 16:00 JST, 7 October (the image shown in Fig. 2), the plume height was $1010 \mathrm{~m}$, which was the maximum value in this study. Looking closely before the 8 October eruption, the plume height increased on 1 and 2 October to $720 \mathrm{~m}$, 


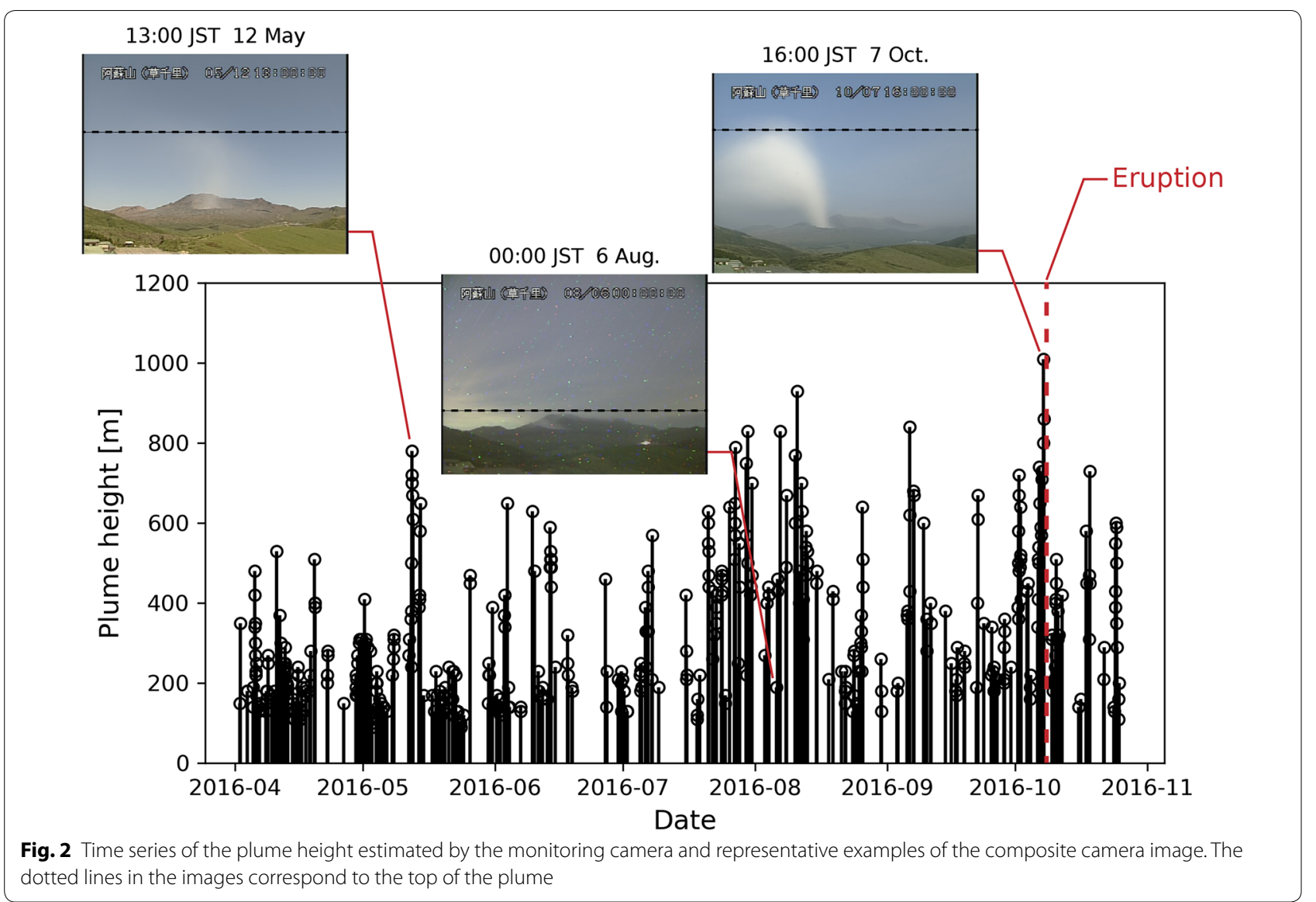

then decreased to $160 \mathrm{~m}$ on 4 October, and increased again to $740 \mathrm{~m}$ on 6 October and $1010 \mathrm{~m}$ on 7 October.

The maps of 10-day and monthly averaged $\mathrm{SO}_{2} \mathrm{PBL}$ VCDs are shown in Figs. 3 and 4, respectively. Those of 10-day and monthly averaged $\mathrm{SO}_{2}$ TRL VCDs are shown in Additional file 1: Figures S3 and S4, respectively. In many maps shown in Figs. 3 and 4, high $\mathrm{SO}_{2}$ VCDs around the volcano were observed clearly through the whole study period. In the case of $\mathrm{SO}_{2} \mathrm{TRL}$, though the $\mathrm{SO}_{2}$ VCDs in the volcanic region were often comparable to those in the $\mathrm{SO}_{2}$-free region, high $\mathrm{SO}_{2} \mathrm{VCDs}$ were sometimes found around the volcano (Additional file 1: Figures S3 and S4).

The time series of the 10-day and monthly averaged $\mathrm{SO}_{2}$ PBL and TRL mass are shown in Fig. 5a and Additional file 1: Figure S5a, respectively. The 10-day averaged $\mathrm{SO}_{2}$ mass showed more fluctuations than the monthly one for both PBL and TRL. In the 10-day and monthly averaged $\mathrm{SO}_{2}$ PBL mass, the maximum value was found in early October and August, respectively. The maxima of the 10-day averaged value were also found in middle April, early June, late July, and middle August. Some of these maxima coincide with those of the plume height shown in Fig. 5b, but the detail will be discussed in the supporting information related to cloud fraction (Fig. 5c and Additional file 1: Section 4). The $\mathrm{SO}_{2}$ mass after the explosion was much lower than that before the explosion. The time series of the $\mathrm{SO}_{2}$ TRL mass (Additional file 1: Figure S5a) showed similar trends to that of the $\mathrm{SO}_{2} \mathrm{PBL}$ mass with an exception that the maximum 10-day averaged $\mathrm{SO}_{2}$ mass was observed in middle August.

To clarify the similar temporal variations between the plume height (Fig. 5b) and the $\mathrm{SO}_{2}$ mass, we compare the 10-day averaged $\mathrm{SO}_{2}$ mass with the fourth power of the maximum plume height in the corresponding period (Fig. 5d and Additional file 1: Figure $\mathrm{S} 5 \mathrm{~b})$. We used the fourth power of the plume height because it is proportional to heat discharge rate assuming that the plume is maintained from the steady source (Morton et al. 1956). We added $100 \mathrm{~m}$ to the plume height because the crater rim was $100 \mathrm{~m}$ higher than the crater bottom (Fig. 1). Although some points are plotted far from the fitted line, positive correlation was roughly found between the $\mathrm{SO}_{2}$ mass and the fourth power of the plume height $\left(R^{2}=0.37\right.$ for PBL and 0.28 for TRL; Fig. 5d and Additional file 1: 


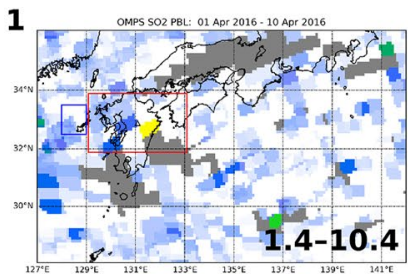

4

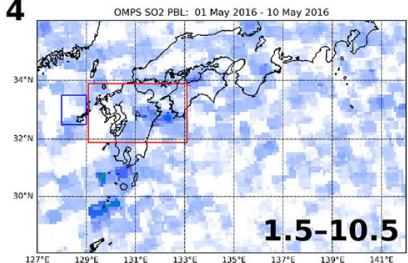

7

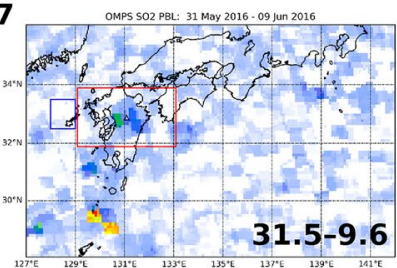

10

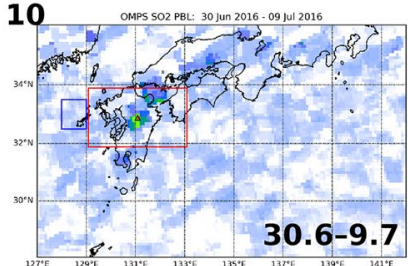

13

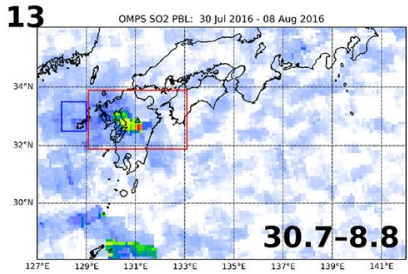

16

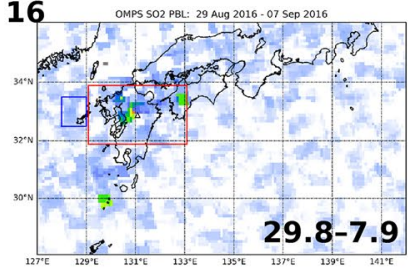

19

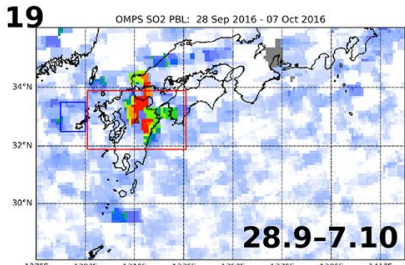

$\mathrm{SO}_{2} \mathrm{PBL}$ 10-days average

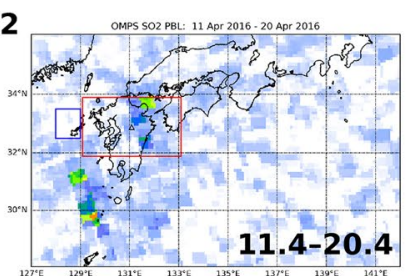

5

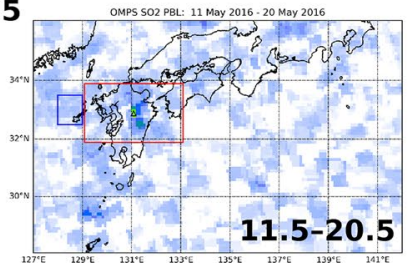

8

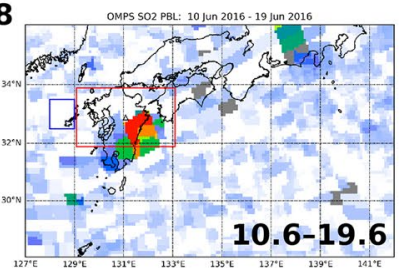

11

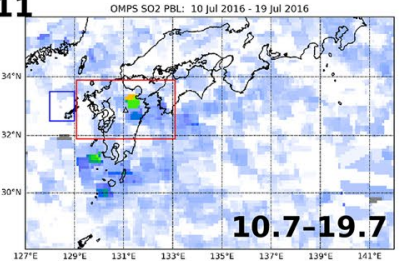

14
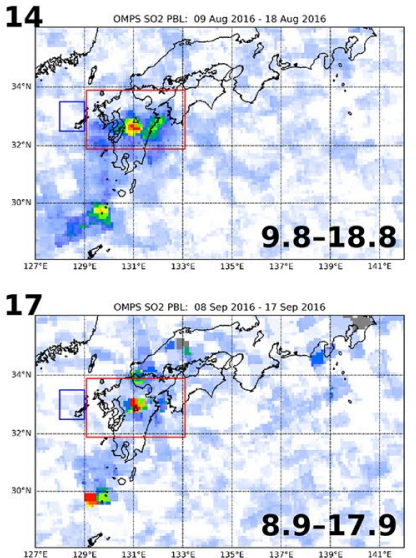

20

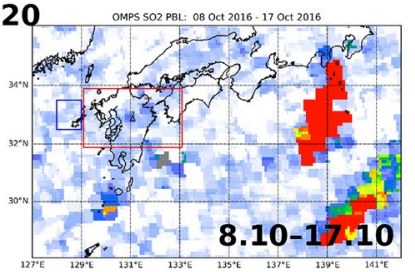

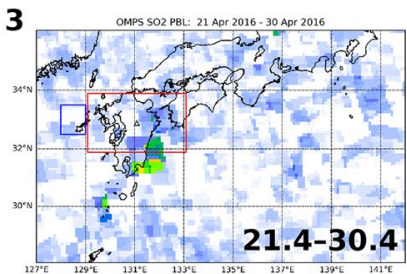

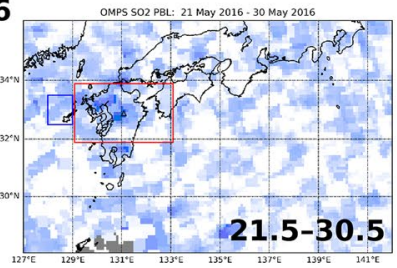

9

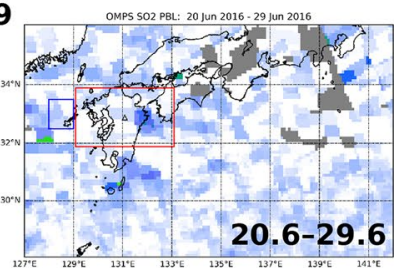

12
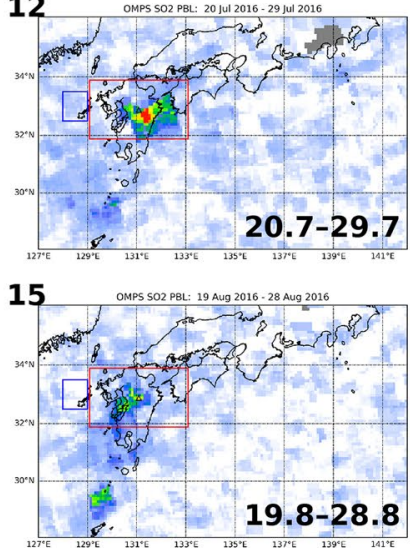

18

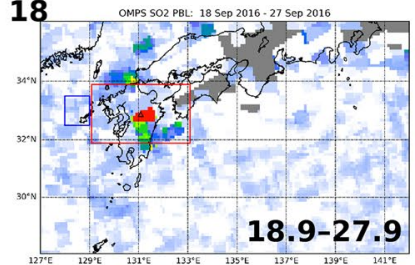

21

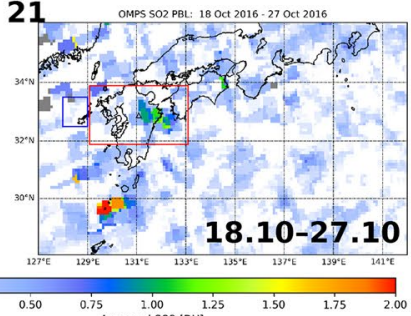

Fig. 3 Maps of the 10-day averaged $\mathrm{SO}_{2}$ PBL VCDs measured by OMPS from 1 April to 27 October 2016. The period for each map is shown at the right bottom of the map (DD.MM-DD.MM). Location of Aso volcano is depicted with the triangle. The volcanic and $\mathrm{SO}_{2}$-free regions for the $\mathrm{SO}_{2}$ mass calculation (see text) are shown with red and blue rectangles, respectively. The high $\mathrm{SO}_{2} \mathrm{VCD}$ around $140^{\circ} \mathrm{E}$ in longitude found in $8.10-$ 17.10 map correspond to the $\mathrm{SO}_{2}$ cloud by the 8 October explosion 

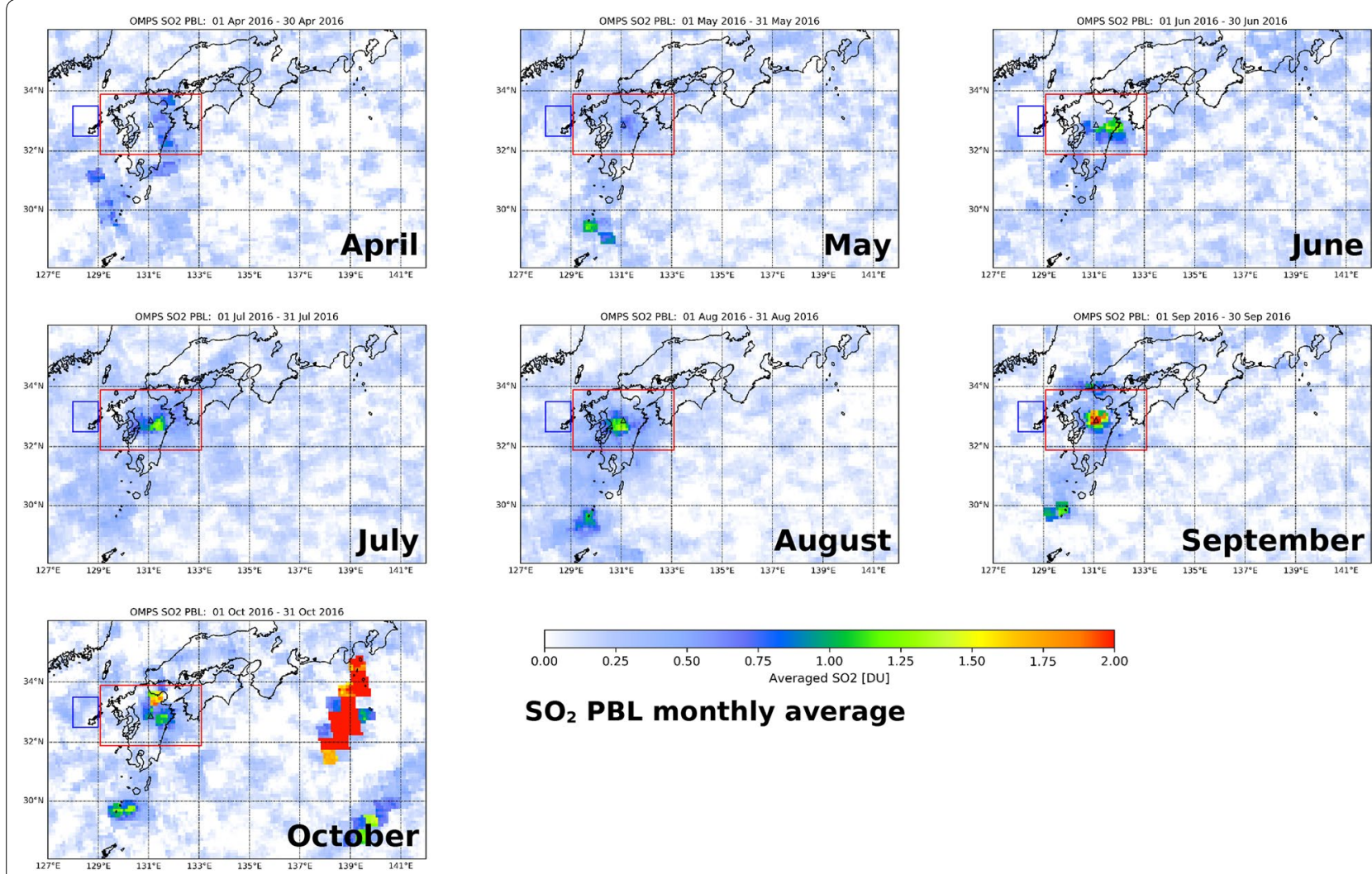

$\mathrm{SO}_{2} \mathrm{PBL}$ monthly average

Fig. 4 Maps of the monthly averaged $\mathrm{SO}_{2}$ PBL VCDs measured by OMPS from April to October 2016. The triangle and the red and blue rectangles are as same as those in Fig. 3. The high $\mathrm{SO}_{2} \mathrm{VCDs}$ around $140^{\circ} \mathrm{E}$ in longitude found in October map correspond to the $\mathrm{SO}_{2}$ cloud by the 8 October explosion

Figure S5b). The points far from the fitted line can be dismissed because they are influenced by the cloud fraction problem (details are written in Additional file 1: Section 4). The influence of the wind speed on the plume height was not found in these plots (Additional file 1: Figure S7). A rough positive correlation was also found between the $\mathrm{SO}_{2}$ mass and the $\mathrm{SO}_{2}$ flux measured by car traverses $\left(R^{2}=0.41\right.$ for PBL and 0.23 for TRL; Fig. 5b, e; Additional file 1: Figure S6 and Section 5).

The daily $\mathrm{SO}_{2}$ mass on 2, 6, and 7 October was so high that it was able to be calculated (Fig. $5 \mathrm{f}-\mathrm{h}$ ), when the plume height was also high as mentioned above. The daily $\mathrm{SO}_{2}$ TRL mass on 2, 6, and 7 October was calculated to be 769,434 , and 1120 tons, respectively. The erupted $\mathrm{SO}_{2}$ of the 8 October phreatomagmatic explosion was captured on the daily map on the same day (Fig. 5i). Location of the $\mathrm{SO}_{2}$ cloud detected by OMPS is almost the same as that detected by a meteorological satellite Himawari-8 (Ishii et al. 2018). The $\mathrm{SO}_{2}$ mass emitted by the explosion was estimated to be 10,810 tons.

\section{Discussion and concluding remarks}

By comparing Fig. $5 \mathrm{a}$ and $\mathrm{b}$, the time series of the plume height, the averaged $\mathrm{SO}_{2}$ mass, and the $\mathrm{SO}_{2}$ flux showed similar temporal variations. Although the correlation between the plume height and the $\mathrm{SO}_{2}$ mass was not good as shown in Fig. 5d and Additional file 1: Figure S5b, the rough positive correlation was found. A similar positive correlation was also found between the $\mathrm{SO}_{2}$ mass and the $\mathrm{SO}_{2}$ flux observed by JMA (Fig. 5e and Additional file 1: Figure S6). These correlations likely indicate that, although the correlations were rough, the degassing system represented by the heat discharge rate and $\mathrm{SO}_{2}$ flux ( $=\mathrm{SO}_{2}$ mass) had been stable during the whole study period, except for some data in middle May, middle August, and early October (points far from the fitted line in Fig. 5d, details are written in Additional file 1: Section 4).

As found in the time series of both the plume height and the $\mathrm{SO}_{2}$ mass, the degassing activity was intensified especially in middle August. Then, both values decreased in September, and some extremely high values were observed again in early October (Fig. 5a, b). The maxima 

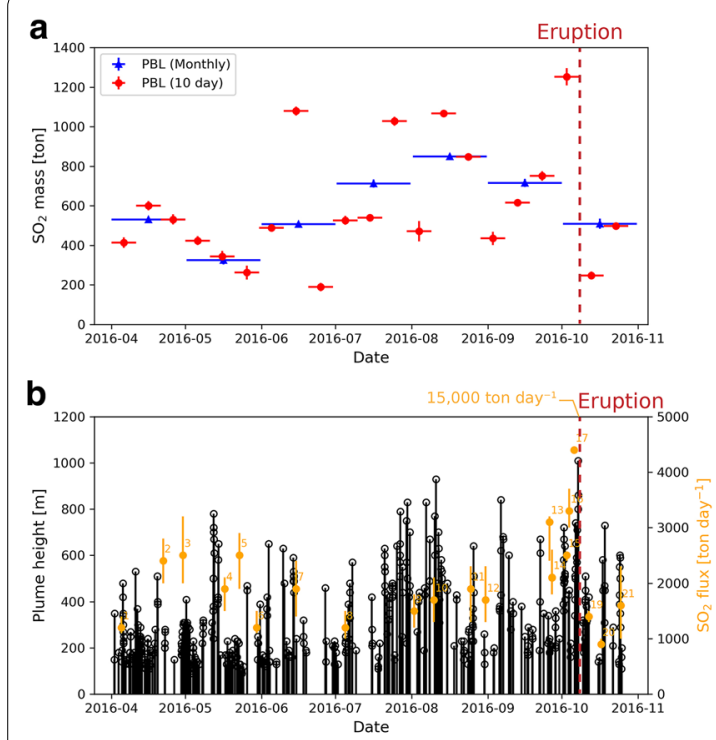

C

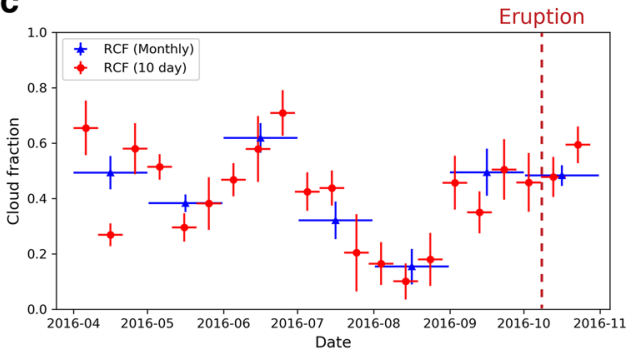

d

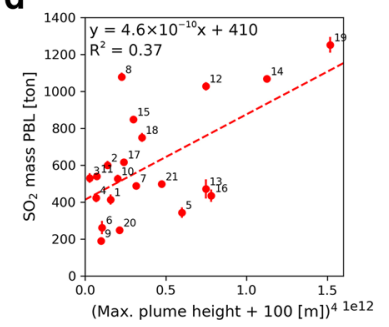

e

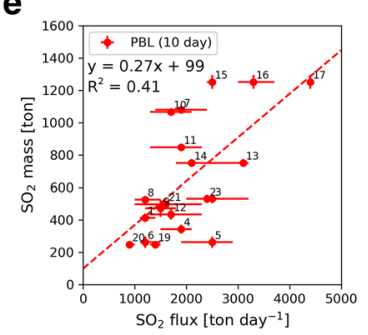

f

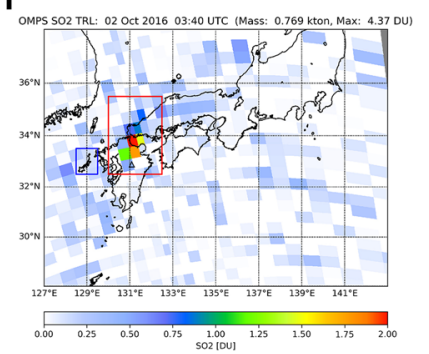

g

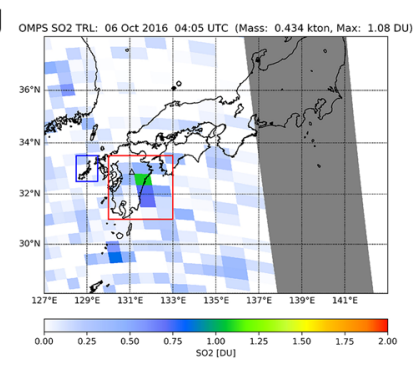

h

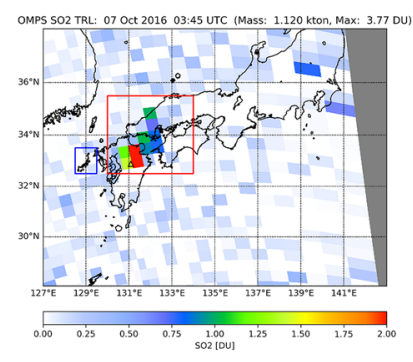

i

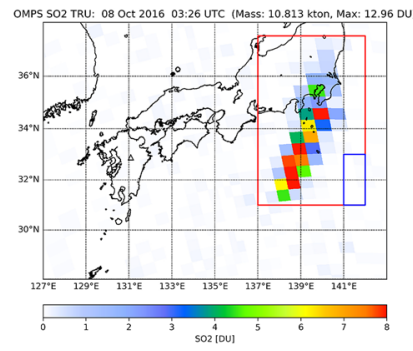

Fig. 5 a The time-averaged (10-days and monthly) $\mathrm{SO}_{2}$ PBL mass emitted by the passive degassing of Aso volcano estimated by OMPS. b Time series of the plume height (black line, from Fig. 2) and $\mathrm{SO}_{2}$ flux (orange point). The $\mathrm{SO}_{2}$ flux data are measured by car traverses by JMA (http://www. data.jma.go.jp/svd/vois/data/fukuoka/rovdm/Asosan_rovdm/gas/gas.html). The error bars correspond to maximum and minimum $\mathrm{SO}_{2}$ fluxes obtained by multiple traverses. The text "15,000 ton day ${ }^{-1 "}$ shown in the upper part corresponds to the $\mathrm{SO}_{2}$ flux measured on 7 October $2016 . \mathbf{c}$ The time-averaged (10-days and monthly) and spatial-averaged cloud fraction of the OMPS data in the volcanic region (red rectangle in Figs. 3 and 4). d Correlation plot of the 10-days averaged $\mathrm{SO}_{2} \mathrm{PBL}$ mass against the fourth power of the maximum plume height for the corresponding period. The plume height values are converted to those above the crater bottom (= plume height in Fig. $2+100 \mathrm{~m}$, see text). A number on the right shoulder

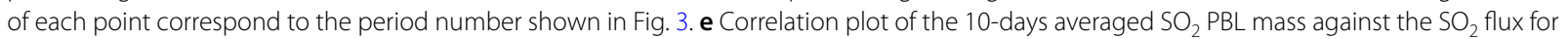
the corresponding period. A number on the right shoulder of each point correspond to the $\mathrm{SO}_{2}$ flux number shown in Fig. $5 \mathrm{~b}$. $\mathbf{f}-\mathbf{i}$ Daily map of $\mathrm{SO}_{2}$ VCDs of $\mathbf{f T R L}$ on 2 October, $\mathbf{g}$ TRL on 6 October, $\mathbf{h}$ TRL on 7 October, and $\mathbf{i}$ TRU on 8 October 2016. The triangle and the red and blue rectangles in $\mathbf{f}-\mathbf{i}$ are as same as those in Fig. 3

in middle August coincides with the inflation timing of the deep magmatic source observed by GNSS networks (JMA 2017). Thus, the input of deep magma might have started since this period. Both values slightly decreased in September. In early October, the plume height started to increase since 1 October, and the $\mathrm{SO}_{2}$ mass also increased on 2 October as shown in the daily $\mathrm{SO}_{2}$ map (Fig. 5f). Both values temporally decreased, but the plume height and the $\mathrm{SO}_{2}$ mass started to increase again on 6 and 7 October, respectively. The decreasing trend from August to October is similar to the decreasing trend of the conduit pressure before Vulcanian explosions proposed by Iguchi et al. (2008). Although the duration of a decrease in this study is much longer than the precursory change in the case of Iguchi et al. (2008), similar accumulation of volcanic gas in the conduit might have occurred in the case of the 8 October eruption of Aso volcano. Following this model, the increase in early October might be explicable by leakage of the accumulated gas just before the explosion. This leakage might have contributed to a decrease of the conduit pressure. Consequently, an interaction of magma with infiltrating waters from the hydrothermal system into the conduit and/or a sudden outgassing of the magma might trigger the explosion.

As mentioned above, the erupted $\mathrm{SO}_{2}$ mass of the 8 October explosion was estimated to be 10,810 tons. According to a petrological study by Saito et al. (2018), sulfur content of the melt inclusions in plagioclases, 
clinopyroxenes, and olivines in scoriae from the 2014 eruption ranged from 0.008 to $0.036 \mathrm{wt} \% \mathrm{~S}$. Assuming that the sulfur content in the pre-eruptive magma is $0.036 \mathrm{wt} \%$ that was the maximum value of the sulfur content, the amount of the pre-eruptive magma for this explosion is estimated to be $1.5 \times 10^{7}$ tons. The total eruptive mass of the 7-8 October explosions was estimated to be $6.0-6.5 \times 10^{6}$ tons with the juvenile magma accounting for $20 \%$ of the deposits (Miyabuchi et al. 2017). Therefore, most of the pre-eruptive magma associated with the explosion might reside in depth, and only the volcanic gas accumulated in depth might be emitted by the explosion. The presence of the accumulated gas is consistent with the model proposed above.

Finally, we emphasize the importance of plume monitoring. Although our result did not show a good correlation between the plume height and the $\mathrm{SO}_{2}$ mass, the plume height measurement can be sufficient to monitor the degassing activity. To reveal the relationship more clearly, accumulation of the data and the precise analysis of the $\mathrm{SO}_{2}$ mass from the passive degassing will be necessary. To the latter case, a recently launched instrument, the Tropospheric Monitoring Instrument (TROPOMI) that can detect the $\mathrm{SO}_{2} \mathrm{VCDs}$ in low altitude at higher spatial resolutions (Theys et al. 2017), might contribute.

\section{Additional file}

Additional file 1. Supplementary information on the analysis method, results, and discussions and supplementary figures. Figure S1. Correlation plot of plume height against wind speed. Figure S2. Boxplot of plume height for each hour and time-series of plume height for every four hours. Figure $\mathbf{S} 3$. Maps of the 10-days averaged $\mathrm{SO}_{2}$ TRL VCDs. Figure S4. Maps of the monthly averaged $\mathrm{SO}_{2}$ TRL VCDs. Figure $\mathrm{S} 5$. Time-series of $\mathrm{SO}_{2} \mathrm{TRL}$ mass and its correlation plot against the fourth power of plume height. Figure S6. Correlation plot of $\mathrm{SO}_{2}$ mass against $\mathrm{SO}_{2}$ flux. Figure S7. Correlation plot of $\mathrm{SO}_{2}$ mass against the fourth power of plume height with wind speed.

\section{Abbreviations}

asl: above sea level; DU: Dobson units; GNSS: global navigation satellite system; JMA: Japan Meteorological Agency; IST: Japan Standard Time; NASA: National Aeronautics and Space Administration; NOAA: National Oceanic and Atmospheric Administration; OMPS: Ozone Mapping and Profiler Suite; SuomiNPP: Suomi National Polar-orbiting Partnership; UTC: Coordinated Universal Time; UV: ultraviolet; VCDs: vertical column densities.

\section{Authors' contributions}

MM performed the whole part of this study. The author read and approved the final manuscript.

\section{Acknowledgements}

The camera images were provided by JMA. The author is grateful to Drs. Akihiko Yokoo, Takehiko Mori, Toshiya Mori, Hiroshi Shinohara, Akihiko Terada, and Genji Saito for data acquisition and discussion. The author would like to thank
Dr. Takahiro Ohkura and three anonymous reviewers for their constructive comments that significantly improved the manuscript.

\section{Competing interests}

The author declares that he has no competing interests.

\section{Availability of data and materials}

The satellite $\mathrm{SO}_{2}$ data are available at https://avdc.gsfc.nasa.gov/pub/data/ satellite/Suomi_NPP/L2/NMSO2-PCA-L2/. The other datasets used in this study are available from the corresponding author on reasonable request.

\section{Funding}

This study received no specific grant from any funding agency.

\section{Publisher's Note}

Springer Nature remains neutral with regard to jurisdictional claims in published maps and institutional affiliations.

Received: 31 March 2018 Accepted: 8 January 2019

Published online: 16 January 2019

\section{References}

Arason P, Petersen GN, Bjornsson H (2011) Observations of the altitude of the volcanic plume during the eruption of Eyjafjallajökull, April-May 2010. Earth Syst Sci Data 3:9-17. https://doi.org/10.5194/essd-3-9-2011

Barberi F, Bertagnini A, Landi P, Principe C (1992) A review on phreatic eruptions and their precursors. J Volcanol Geotherm Res 52:231-246. https:// doi.org/10.1016/0377-0273(92)90046-G

Behncke B, Falsaperla S, Pecora E (2009) Complex magma dynamics at Mount Etna revealed by seismic, thermal, and volcanological data. J Geophys Res 114:B03211. https://doi.org/10.1029/2008JB005882

Bursik M (2001) Effect of wind on the rise height of volcanic plumes. Geophys Res Lett 28:3621-3624. https://doi.org/10.1029/2001GL013393

Campion R (2014) New lava lake at Nyamuragira volcano revealed by combined ASTER and $\mathrm{OMI} \mathrm{SO}_{2}$ measurements. Geophys Res Lett 41:74857492. https://doi.org/10.1002/2014GL061808

Carn SA, Krueger AJ, Arellano SR, Krotkov NA, Yang K (2008) Daily monitoring of Ecuadorian volcanic degassing from space. J Volcanol Geotherm Res 176:141-150. https://doi.org/10.1016/j.jvolgeores.2008.01.029

de Moor JM, Aiuppa A, Pacheco J, Avard G, Kern C, Liuzzo M, Martínez M, Giudice G, Fischer TP (2015) Short-period volcanic gas precursors to phreatic eruptions: insights from Poás Volcano, Costa Rica. Earth Planet Sci Lett 442:218-227. https://doi.org/10.1016/j.epsl.2016.02.056

Flynn L, Long C, Wu X, Evans R, Beck CT, Petropavlovskikh I, McConville G, Yu W, Zhang Z, Niu J, Beach E, Hao Y, Pan C, Sen B, Novicki M, Zhou S, Seftor C (2014) Performance of the Ozone Mapping and Profiler Suite (OMPS) products. J Geophys Res Atmos 119:6181-6195. https://doi. org/10.1002/2013JD020467

Fukui $\mathrm{K}$ (1995) $\mathrm{H}_{2} \mathrm{O}$ and heat discharged from Aso volcano in noneruptive stage. Bull Volcanol Soc Jpn 40:233-248. https://doi.org/10.18940/kazan 40.4_233 (in Japanese with English abstract)

Fukui K, Terada A (2013) Heat and $\mathrm{H}_{2} \mathrm{O}$ discharge rate at the Shinmoedake volcano in February 2011. Q J Seis (Kenshin Jiho) 77:223-228 (in Japanese with English abstract)

Galle B, Oppenheimer C, Geyer A, McGonigle AJS, Edmonds M, Horrocks L (2002) A miniaturised ultraviolet spectrometer for remote sensing of $\mathrm{SO}_{2}$ fluxes: a new tool for volcano surveillance. J Volcanol Geotherm Res 119:241-254. https://doi.org/10.1016/S0377-0273(02)00356-6

Iguchi M, Yakiwara H, Tameguri T, Hendrasto M, Hirabayashi J (2008) Mechanism of explosive eruption revealed by geophysical observations at the Sakurajima, Suwanosejima and Semeru volcanoes. J Volcanol Geotherm Res 178:1-9. https://doi.org/10.1016/j.jvolgeores.2007.10.010

Ishii K, Hayashi Y, Shimbori T (2018) Using Himawari-8, estimation of $\mathrm{SO} 2$ cloud altitude at Aso volcano eruption, on October 8, 2016. Earth Planets Space 70:19. https://doi.org/10.1186/s40623-018-0793-9

Japan Meteorological Agency (JMA) (2017) Annual report on volcanic activities of Aso volcano in 2016. http://www.data.jma.go.jp/svd/vois/data/ 
tokyo/STOCK/monthly_v-act_doc/fukuoka/2016y/503_16y.pdf. Accessed $13 \operatorname{Jan} 2019$

Krueger AJ (1983) Sighting of El Chichón sulfur dioxide clouds with the Nimbus 7 total ozone mapping spectrometer. Science 220:1377-1379. https ://doi.org/10.1126/science.220.4604.1377

Li C, Joiner J, Krotkov NA, Bhartia PK (2013) A fast and sensitive new satellite $\mathrm{SO}_{2}$ retrieval algorithm based on principal component analysis: application to the ozone monitoring instrument. Geophys Res Lett 40:63146318. https://doi.org/10.1002/2013GL058134

Li C, Krotkov NA, Carn S, Zhang Y, Spurr RJD, Joiner J (2017) New-generation NASA Aura Ozone Monitoring Instrument (OMI) volcanic $\mathrm{SO}_{2}$ dataset: algorithm description, initial results, and continuation with the SuomiNPP Ozone Mapping and Profiler Suite (OMPS). Atmos Meas Tech 10:445-458. https://doi.org/10.5194/amt-10-445-2017

Matsushima N, Shinohara H (2006) Visible and invisible volcanic plumes. Geophys Res Lett 33:L24309. https://doi.org/10.1029/2006GL026506

Miyabuchi Y, Terada A (2009) Subaqueous geothermal activity revealed by lacustrine sediments of the acidic Nakadake crater lake, Aso Volcano, Japan. J Volcanol Geotherm Res 187:140-145. https://doi.org/10.1016/j. jvolgeores.2009.08.001

Miyabuchi Y, Maeno F, Nakada S, Nagai M, lizuka Y, Hoshizumi H, Tanaka A, Itoh J, Kawanabe Y, Oishi M, Yokoo A, Ohkura T (2017) The October 7-8, 2016 eruptions of Nakadake crater, Aso Volcano, Japan and their deposits. Paper presented at Japan geoscience union-American geophysical union joint meeting. Chiba, Japan, SVC47-11, 22 May 2017. (in Japanese with English abstract)

Miyabuchi Y, lizuka Y, Hara C, Yokoo A, Ohkura T (2018) The September 14, 2015 phreatomagmatic eruption of Nakadake first crater, Aso Volcano, Japan: eruption sequence inferred from ballistic, pyroclastic density current and fallout deposits. J Volcanol Geotherm Res 351:41-56. https://doi. org/10.1016/j.jvolgeores.2017.12.009

Morton BR, Taylor G, Turner JS (1956) Turbulent gravitational convection from maintained and instantaneous sources. Proc R Soc A 234:1-23. https:// doi.org/10.1098/rspa.1956.0011

Ohsawa S, Saito T, Yoshikawa S, Mawatari H, Yamada M, Amita K, Takamatsu N, Sudo Y, Kagiyama T (2010) Color change of lake water at the active crater lake of Aso volcano, Yudamari, Japan: is it in response to change in water quality induced by volcanic activity? Limnology 11:207-215. https://doi. org/10.1007/s10201-009-0304-6

Ono K, Watanabe K (1985) Geological map of Aso volcano 1:50,000. Geological Survey of Japan. https://gbank.gsj.jp/volcano/Act_Vol/aso/index-e.html. Accessed 13 Jan 2019

Rouwet D, Sandri L, Marzocchi W, Gottsmann J, Selva J, Tonini R, Papale P (2014) Recognizing and tracking volcanic hazards related to nonmagmatic unrest: a review. J Appl Volcanol 3:17. https://doi.org/10.1186/ s13617-014-0017-3

Saito G, Ishizuka O, Ishizuka Y, Hoshizumi H, Miyagi I (2018) Petrological characteristics and volatile content of magma of the 1979, 1989, and 2014 eruptions of Nakadake, Aso volcano, Japan. Earth Planets Space 70:197. https://doi.org/10.1186/s40623-018-0970-x

Sano Y, Kagoshima T, Takahata N, Nishio Y, Roulleau E, Pinti DL, Fischer TP (2015) Ten-year helium anomaly prior to the $2014 \mathrm{Mt}$ Ontake eruption. Sci Rep 5:13069. https://doi.org/10.1038/srep13069

Seftor CJ, Jaross G, Kowitt M, Haken M, Li J, Flynn LE (2014) Postlaunch performance of the Suomi national polar-orbiting partnership ozone mapping and profiler suite (OMPS) nadir sensors. J Geophys Res Atmos 119:44134428. https://doi.org/10.1002/2013JD020472

Shimbori T, Fukui K (2013) Eruption column height and magma discharge rate as inferred from camera images - the eruption of the Shinmoedake Volcano on March 13, 2011. Q J Seis (Kenshin Jiho) 77:119-138 (in Japanese)

Shinohara H, Yoshikawa S, Miyabuchi Y (2015) Degassing activity of a volcanic crater lake: Volcanic plume measurements at the Yudamari crater lake, Aso Volcano, Japan. In: Rouwet D, Christenson B, Tassi F, Vandemeulebrouck J (eds) Volcanic lakes. Springer, Berlin, pp 201-217. https://doi. org/10.1007/978-3-642-36833-2

Stoiber RE, Maliconico LL, Williams SN (1983) Use of the correlation spectrometer at volcanoes. In: Tazieff H, Sabroux JC (eds) Forecasting volcanic events. Elsevier, Amsterdam, pp 425-444

Terada A, Hashimoto T (2017) Variety and sustainability of volcanic lakes: response to subaqueous thermal activity predicted by a numerical model. J Geophys Res Solid Earth 122:6108-6130. https://doi. org/10.1002/2017JB014387

Terada A, Ida Y, Ohminato T (2003) Automatic image recording system using the Windows PCs: application to the eruption columns of Miyakejima volcano, Japan. Bull Volcanol Soc Jpn 48:445-459. https://doi.org/10.18940/ kazan.48.6_445 (in Japanese with English abstract)

Terada A, Ida Y, lijima S, Yoshimoto M, Shimano T (2005) The kinematic features of volcanic clouds: a series of small eruptions from 15 to 18, September 2004, at Asama volcano, Japan. Bull Volcanol Soc Jpn 50:555-565. https:// doi.org/10.18940/kazan.50.6_555 (in Japanese with English abstract)

Terada A, Hashimoto T, Kagiyama T (2012) A water flow model of the active crater lake at Aso volcano, Japan: fluctuations of magmatic gas and groundwater fluxes from the underlying hydrothermal system. Bull Volcanol 74:641-655. https://doi.org/10.1007/s00445-011-0550-4

Theys N, De Smedt I, Yu H, Danckaert T, van Gent J, Hörmann C, Wagner T, Hedelt P, Bauer H, Romahn F, Pedergnana M, Loyola D, Van Roozendael M (2017) Sulfur dioxide retrievals from TROPOMI onboard Sentinel-5 Precursor: algorithm theoretical basis. Atmos Meas Tech 10:119-153. https://doi. org/10.5194/amt-10-119-2017

Volcanological Division, Seismological and Volcanological Department JMA (2014) Installation of new volcano monitoring systems for 47 volcanoes in Japan. Q J Seis (Kenshin Jiho) 77:241-310 (in Japanese with English abstract)

\section{Submit your manuscript to a SpringerOpen ${ }^{\odot}$ journal and benefit from:}

- Convenient online submission

- Rigorous peer review

- Open access: articles freely available online

- High visibility within the field

- Retaining the copyright to your article

Submit your next manuscript at $\boldsymbol{\nabla}$ springeropen.com 